\title{
Ihanan kaupungin askelmerkit
}

Anne Jarva

Mari Vaattovaara, Anssi Joutsiniemi, Jenni Airaksinen ja Markku Wilenius (2021). Kaupunki politiikassa. Yhteiskunta, ihminen ja ihana kaupunki.

Tampere: Vastapaino

ISBN 978-951-768-928-1, $261 \mathrm{s.}$

Neljän eri alan tutkijan poleeminen puheenvuoro tarjoaa tietoa ja näkemyksiä suomalaisen kaupunkipolitiikan tilasta ja kehittämismahdollisuuksista. Tavoitteena on kokonaiskuvan rakentaminen ja keskustelun herättäminen ihanasta kaupungista.

Mari Vaattovaara, Anssi Joutsiniemi, Jenni Airaksinen ja Markku Vilenius yhdistävät kirjoituksessaan kaupunkimaantieteen, kaupunkikehityksen, kuntajohtamisen ja tulevaisuuden tutkimuksen näkökulmat monipuoliseksi ja uutta avaavaksi kokonaisuudeksi. Konkreettisten ratkaisujen sijaan he esittävät teesejä ja askeleita suuntaamaan ja rakentamaan kaupunkipolitiikkaa. Lisäksi he kannustavat lukijoita oman elinympäristönsä laadun arviointiin.

\section{Kaupunkioikeudet ja velvollisuudet uusiksi}

Kirjoittajien mielestä hallinnollisiin rajoihin perustuva kaupunkikäsitys ei enää vastaa todellisuutta, kun mikä tahansa kunta voi kutsua itseään kaupungiksi ja toisaalta kasvukeskuksista on tullut liikkumisen ja logistiikan ehdoilla muotoutuneita kaupunkiseutuja. He pitävät ongelmallisena myös sitä, että kaupungit ovat menettäneet hallinnollisen erityisyytensä ja niistä on tullut kansallisia tavoitteita toteuttavia "hyvinvointiyhtenäiskuntia." Heidän mukaansa pakkaa sekoittaa lisäksi hallintojärjestelmän kerrostuminen: periaatteessa selkeän valtio-kunta-suhteen rinnalle on syntynyt erilaisia lakisääteisiä ja vapaamuotoisia hallinnollisia "apparaatteja", yhteistoimintaelimiä ja kumppanuuksia.

Kaupunkipolitiikan kannalta hyvinvointiyhtenäiskuntakehitys ja hallintojärjestelmän kerrostuminen ovat kirjoittajien mukaan johtaneet siihen, että kaupungit ovat käytännössä menettäneet autonomiansa ja kykynsä ohjata alueellaan tapahtuvaa kehitystä. Teeseissään he kysyvät, voisiko tai pitäisikö kaupungeille palauttaa lainsäädännöllinen erityisasema muihin kuntiin verrattuna: voitaisiinko esimerkiksi määritellä kriteerit, joilla kaupunki tai kaupunkiseudullinen kuntayhtymä voi saada erityisoikeuksia suhteessa valtioon erikseen sovittavilla toiminta-alueilla. Avoimeksi jää, tarkoittavatko kirjoittajat 
tässä maantieteellisesti rajattua toiminta-aluetta tai mahdollisesti johonkin kaupunkimaiseen toimintoon tai ilmiöön liittyvää erityistä säätelyä.

\section{Tavoitteeksi ihmiselle ihana kaupunki}

Kirjoittajat paneutuvat kaupunkien suunnitteluun ja rakentamiseen tavalla, joka on uutta kaupunkipolitiikan kentällä. He haastavat terveellä tavalla kaupunkien tiivistämispyrkimyksen ja vaativat huomion siirtämistä rakentamisen määrästä yksittäistä asuntoa, rakennusta tai korttelia laajempaan, ihmisen arjen kannalta merkitykselliseen elinympäristöön.

Kaavoitusta ja rakentamista koskevaa lainsäädäntöä kirjoittajat pitävät yhdyskuntarakenteen hallinnan ja elinympäristön laadun kannalta riittämättömänä. Heidän mielestään rakennuslain aikaisen taaja-asutuskiellon poistaminen ja korvaaminen suunnittelutarveharkinnalla on osaltaan johtanut yhdyskuntarakenteen hajautumiseen. Tästä olen eri mieltä, sillä lupaharkinnan kriteerit ovat säilyneet käytännössä ennallaan. Kirjoittajat väittävät myös, ettei laissa ole asetettu velvoittavia tavoitteita kaavoituksen laadulle. Väite on mielestäni harhaanjohtava, sillä eri kaavatasoille säädetyt sisältövaatimukset ovat käytännössä juuri tällaisia laadullisia tavoitteita, joihin voidaan muutoksenhaussa vedota. Kokonaan toinen asia on se, pitäisikö vireillä olevassa lakiuudistuksessa lupakriteerejä kiristää tai laatutavoitteita täsmentää.

Kirjoittajat vaativat teeseissään kaupunkipolitiikan tavoitteeksi "ihmiselle ihanaa kaupunkia". Ihanuudella he tarkoittavat laadullisia kriteerejä, tavoitteita ja ominaisuuksia, joista voidaan keskustella ja joihin suunnittelun ja päätöksenteon tulisi tähdätä. Kirjoittajat eivät kerro, kuka tai mikä nämä laadulliset ominaisuudet ja kriteerit määrittelisi. Jatkokeskustelun varaan jää myös pohdinta siitä, miten näiden laadullisten ominaisuuksien ja kriteerien toteutuminen varmistettaisiin - käytettäisiinkö keppiä eli määräyksiä ja sanktioita vai porkkanaa, eli muodossa tai toisessa jaettavia kannustimia ja palkkioita.

\section{Miten suhtautua hyhmään?}

Kirjassa on oma lukunsa "hyhmälle", jolla kirjoittavat tarkoittavat erilaisia kaupunkeihin vaikuttavia hallinnollisia rakenteita ja ohjauspyrkimyksiä. Kirjoittajia huolestuttaa, kun "hyhmään" sekoittuvat niin lainsäädäntöön perustuvat hallinnolliset käytännöt kuin sopimusvapauteen nojautuvat kumppanuudet.

Kuntien ja valtion välisiin maankäytön, asumisen ja liikenteen sopimuksiin (MAL-sopimuksiin) liittyy kirjoittajien mielestä demokratiavaje, kun sopimukset syntyvät ilman lakisääteistä vuorovaikutusprosessia, laatukriteereitä tai objektiivista toteutumisen seurantaa - toisin sanoen tiivistämisen ja tehokkuuden tavoitteita määritellään ja toteutetaan epävirallisin ja läpinäkymät- 
tömin käytännöin. Kun lisäksi asuntotuotantotavoitteet on sidottu asuntojen lukumäärään, seurauksena on kirjoittajien mukaan asuntokannan rakenteen vääristyminen, pienten asuntojen suhteettoman suuri määrä sekä asuntosuunnittelun periaatteiden ja etenkin laadullisten tavoitteiden hylkääminen.

Kuntien ja yksityisten toimijoiden välisen ns. kumppanuuskaavoituksen ongelmana kirjoittajat pitävät epäsymmetriaa: kumppanuudesta sopivat julkisyhteisö ja yksityinen toimija, eivätkä kansalaiset pääse mukaan. Kansalaisella on kuitenkin muita vaikutuskeinoja, joita kirjoittajat eivät mainitse: kumppanuuskaavoitusta koskevat samat lakisääteiset vuorovaikutusmenettelyt kuin muutakin kaavoitusta. Toiseksi sopimuksista päätetään kunnissa edustuksellisen demokratian pelisääntöjen mukaan. Kolmanneksi mikään kumppanuushengessä tehty sopimus ei voi ohittaa kaavoja koskevia lain vaatimuksia.

\section{Uudelleen muotoiltua asuttamisen politiikkaa}

Kirjoittajat vertaavat kaupunkipolitiikkaa asuttamiseen, pyrkimykseen vastata ihmisen asumisen tarpeisiin, väestön siirtymiin ja uuden asutuksen perustamiseen. He haluavat nyt nostaa keskiöön myös asuntojen ja asuinympäristön laadun, omistajuuden ja osallisuuden.

Uudenlaista asuttamisen politiikkaa kaivataan kirjoittajien mielestä etenkin segregaation eli alueellisen eriytymisen hillitsemiseksi. Nykyisiä rakentamisen volyymiin, hallintamuotoihin ja tulotasaukseen perustuvat asuntopoliittisia keinoja kirjoittajat pitävät riittämättöminä. Auttaisiko sitten kirjoittajien peräänkuuluttama huomion kiinnittäminen kaupunkiseutujen erityiskysymyksiin, kuten väestörakenteen muutoksiin, elinympäristön laatuun ja asukkaiden valintoja ohjaaviin naapurustokokemuksiin?

\section{Myötävaikuttamisfederalismia ja laatutavoitteita}

Kirjan lopussa kirjoittajat esittävät askeleita kaupunkipolitiikan rakentamiseksi. Osa askeleista on mielestäni tyypillistä ohjelmapuhetta: oman alan hännän nostatusta, tiedon kerryttämistä, tavoitteiden määrittelyä ja toteutumisen seurantaa. Uutta on vaatimus rakentaa kaupunki-valtio-suhde uudelleen "myötävaikuttamisfederalismin hengessä" eli siten, että kaupungit voisivat valtiotoimijoiden kanssa tasa-arvoisina tuoda pöytään omat tietonsa ja näkemyksensä, kun lainsäädäntöä tai muita uudistuksia suunnitellaan. Määrittelemätön kumppanuus ei kirjoittajien mielestä enää riitä, vaan tueksi tarvitaan kaupunkien asemaa vahvistavaa säätelyä. Erityisen ilahduttava on vaatimus siitä, että kaupunkipolitiikan tavoitteita tulisi kohdentaa kaupunkielämän ja lähiympäristön laatuun - ihanan kaupungin rakentumiseen. 
Kaupunki politiikassa -kirjan mielenkiintoisinta antia on kaupunkipolitiikan, kaupunkisuunnittelun, lainsäädännön ja toimintatapojen törmäyttäminen. Mukana on paljon arvokasta tietoa, mutta myös kärjekkäitä ilmaisuja ja provosoivia väitteitä. Kaupunkipolitiikan lisäksi ne tarjoavat pohdittavaa myös maankäyttö- ja rakennuslain uudistamiseen. 